Zeszyty Naukowe Szkoły Głównej Gospodarstwa Wiejskiego

Ekonomika i Organizacja Gospodarki Żywnościowej nr 109, 2015: 27-42

\title{
Bogdan Klepacki
}

Wydział Nauk Ekonomicznych

Szkoła Główna Gospodarstwa Wiejskiego w Warszawie

Edyta Piątek, llona Dziedzic-Jagocka

Wydział Zarzadzania i Modelowania Komputerowego

Politechnika Świętokrzyska w Kielcach

\section{Wielostopniowy rachunek kosztów zmiennych na przykładzie przedsiębiorstwa}

\section{Wstęp}

We współczesnym świecie, w warunkach globalizacji, otoczenie i przedsiębiorstwo charakteryzuje bardzo duża zmienność. Ciagłym przeobrażeniom ulegają mechanizmy rynkowe, układy sił na rynku, potrzeby klientów. Współcześnie przedsiębiorstwo jest organizmem gospodarczym niezwykle złożonym. Zatrudnia ludzi reprezentujących różne profesje. Wyposażone jest w skomplikowane aparaty i urządzenia techniczne będące efektem postępu technicznego. Działalność gospodarcza realizowana przez przedsiębiorstwo jest swoistą ,,walką" $\mathrm{z}$ otoczeniem, a zarządzanie przedsiębiorstwem to skomplikowany proces uzależniony od wielu czynników. Trudno sobie wyobrazić zarządzanie przedsiębiorstwem bez dokonania kompleksowej analizy kosztów. Decyzje powinny być podejmowane na podstawie racjonalnych przesłanek i rzetelnych informacji o przedsiębiorstwie i jego otoczeniu. Dlatego coraz więcej przedsiębiorstw wykorzystuje coraz nowocześniejsze metody zarządzania kosztami, zapominając o najprostszym, tradycyjnym i jednocześnie często najbardziej użytecznym narzędziu - rachunku kosztów zmiennych.

Celem artykułu jest rozpoznanie zasad prowadzenia rachunku kosztów zmiennych z jego praktyczną egzemplifikacją na przykładzie wybranego przedsiębiorstwa. 


\section{Podstawowe informacje o kosztach zmiennych}

Przedsiębiorstwo wykorzystuje różnorodne zasoby w celu osiąnnięcia określonych korzyści. Zużyte zasoby, do których zaliczamy między innymi: pracowników, materiały, maszyny, urządzenia, budynki czy nowe technologie, wyrażone w pieniądzu są kosztami. Możliwości zastosowania zasobów zależą od celu działania danej organizacji. Koszty stanowią więc pewien efekt celowego wykorzystania zasobów. Do menedżerów należy wybór najbardziej racjonalnego zestawienia zasobów dla osiągnięcia największych korzyści dla przedsiębiorstwa. W związku z tym zarządzający w swojej pracy muszą podejmować różnorodne decyzje ekonomiczne, które poprzedzone są szeregiem rachunków decyzyjnych, polegających na zestawieniu nakładów i efektów dla przyjętych wariantów działania. Koszty stanowią więc punkt wyjścia myślenia ekonomicznego, należą do fundamentalnych kryteriów decyzji $\mathrm{w}$ przedsiębiorstwie.

W literaturze definiuje się koszt jako ,wyrażone w pieniądzu lub jego ekwiwalentach wykorzystanie (zużycie) zasobów (środków), związanych $\mathrm{z}$ prowadzoną $\mathrm{w}$ określonych warunkach działalnością, $\mathrm{w}$ celu osiągnięcia w bieżącym okresie lub w przyszłości korzyści dla organizacji” [Świderska 2003, s. 1-2].

Rozszerzając podaną definicję, można określić następujące cechy kosztów [Matuszek i in. 2011, s. 32-33]:

- $\quad$ koszt jest wyrażony wartościowo, zwykle podawany w jednostkach monetarnych, wymiarem może być np. dolar (USD), złoty (PLN),

- koszt wskazuje zużyte zasoby (mające postać nakładu pracy żywej, materiałów, maszyn, urządzeń, budynków czy prawa własności),

- zasoby zostały zużyte, aby przedsiębiorstwo osiągnęło założony cel (generowanie zysku),

- $\quad$ koszt nieodłącznie związany jest z czasem (cel przedsiębiorstwa określany jest dla jakiegoś czasu, zwanego okresem sprawozdawczym),

- $\quad$ koszt stanowi określenie tego co było, co w przeszłości zostało wykonane.

Działanie każdego przedsiębiorstwa jest nierozerwalnie związane z generowaniem kosztów. Ich ranga w podejmowaniu decyzji przez menadżerów wynika stąd, iż nie można nie ponosić kosztów w działalności gospodarczej, lecz w dużej mierze można je kontrolować i ograniczać. Nadzorowanie kosztów wynika z głównych założeń każdej organizacji - osiaggnięcia celu jak najmniejszym kosztem, czy też odwrotnie - poświęcenia określonych nakładów i uzyskania z nich największego efektu. Racjonalne gospodarowanie daje możliwość kształtowania właściwej relacji między kosztami generowanymi przez przedsiębiorstwo a uzyskanymi przychodami [Gabrusewicz i in. 1998, s. 39]. W celu osią- 
gnięcia pełnej wiedzy o ponoszonych kosztach i właściwego wykorzystania tej wiedzy w bieżących i strategicznych decyzjach zarządczych konieczne jest dokładne poznanie cech kosztów w różnych przekrojach klasyfikacyjnych.

Klasyfikacja kosztów polega na podziale ogólnej sumy kosztów jednostki gospodarczej na różne grupy, stosownie do przyjętego kryterium klasyfikacyjnego. Klasyfikacja kosztów umożliwia poznanie struktury kosztów oraz stanowi podstawę rachunku kosztów. Wybór kryterium kosztów zależy od rodzaju i celu rachunku ekonomicznego. $Z$ tego względu klasyfikacja kosztów przeprowadzana jest na potrzeby [Nowak 2002, s. 169]:

- wyceny zapasów i ustalenia wyniku finansowego,

- podejmowania decyzji i planowania,

- $\quad$ kontroli działalności.

Za kryterium podziału kosztów przedsiębiorstwa służą najczęściej: rodzaje działalności, funkcje realizowane w przedsiębiorstwie (jak np. zaopatrzenie, zbyt, produkcja, zarządzanie itd.), zużywane rodzaje czynników produkcji (koszty rodzajowe), wytwarzane wyroby i usługi (nośniki kosztów), reagowanie na stopień wykorzystania posiadanych zdolności produkcyjnych, podmioty wewnętrzne itd. Każda z wyodrębnionych w przedsiębiorstwie struktur kosztów ma na celu dostarczenie informacji o kosztach dla procesów decyzyjnych i kontroli racjonalności działań [Jarugowa i in. 1994, s. 64-65].

Jedno $\mathrm{z}$ fundamentalnych kryteriów - relacja w stosunku do rozmiarów produkcji - dzieli koszty na zmienne i stałe.

Koszty stałe to te, które niezależnie od zmian wielkości produkcji pozostają $w$ pewnych granicach na prawie jednakowym poziomie, reagując nieznacznie lub w ogóle na zmiany rozmiarów produkcji. Należą do nich: opłaty czynszowe, amortyzacja środków trwałych (obliczana metodą liniowa), koszty zarządu jednostki, w tym wynagrodzenia personelu kierowniczego i administracyjnego itp. Koszty stałe można podzielić na dwie kategorie: [Matuszewicz i Matuszewicz 1999]:

- koszty bezwzględnie stałe nie reagują na zmiany wielkości produkcji. Charakter kosztów bezwzględnie stałych mają czynsze i amortyzacja środków trwałych, a zwłaszcza amortyzacja budynków,

- koszty względnie stałe zachowują stały poziom do momentu osiagnięcia określonego poziomu wykorzystania zdolności produkcyjnych; po przekroczeniu tego poziomu koszty te wzrastają i utrzymują się na stałym poziomie przez pewien okres mimo wzrostu produkcji.

Koszty stałe są traktowane jako koszty gotowości do produkcji. Koszty te przeliczone na jednostkę produkcji są kosztami malejącymi: przy wzroście wielkości produkcji na jednostkę produkcji przypada coraz mniejsza kwota kosztów stałych [Nowak i in. 2004, s. 50]. 
Koszty zmienne są to koszty, które w miarę wzrostu produkcji rosna, a wraz ze spadkiem produkcji maleją. Wyróżnia się trzy odmienne typy zmienności kosztów:

- $\quad$ koszty zmienne proporcjonalnie rosną proporcjonalnie do wzrostu produkcji, np. koszty płac bezpośrednich przy stosowaniu akordowego systemu płac, koszty energii służącej do napędu maszyn itd.,

- $\quad$ koszty zmienne progresywnie rosną bardziej niż produkcja. Są zjawiskiem negatywnym i mogą być akceptowane tylko w krótkich okresach i w wyjątkowych sytuacjach, np. koszty płac godzin nadliczbowych, w niedziele i święta są odpowiednio wyższe od stawek płaconych w normalne dni robocze,

- $\quad$ koszty zmienne degresywnie rosną wolniej od wzrostu produkcji.

Przedstawiony powyżej podział stoi u podstaw najstarszego rachunku kosztów - rachunku kosztów zmiennych.

\section{Założenia rachunku kosztów zmiennych}

Rachunek kosztów zmiennych to ogół działań polegających na ujęciu, zgrupowaniu, mierzeniu ilościowo i wartościowo za pewien okres czasu oraz zinterpretowaniu kosztów zmiennych w celu uzyskania możliwie wszechstronnych informacji niezbędnych dla ustalenia wyników i sposobu kierowania przedsiębiorstwem.

W rachunku kosztów zmiennych dochodzi do podziału kosztów całkowitych przedsiębiorstwa na koszty stałe i koszty zmienne. Wyrobom przypisuje się tylko część poniesionych w przedsiębiorstwie kosztów, a mianowicie koszty zmienne. Koszty stałe są w rachunku kosztów zmiennych traktowane jako koszty gotowości do produkcji [Sobańska 2003, s. 107].

Koszty zmienne są to takie pozycje kosztów, których poziom zależy od wielkości produkcji. Oznacza to, że przy zmianach wielkości produkcji poziom tych kosztów ulega także zmianie, przy czym zazwyczaj wraz ze wzrostem wielkości produkcji wzrastają także koszty zmienne, ponieważ zwiększenie produkcji wymaga poniesienia większych nakładów - czynników produkcji [Nowak i in. 2004, s. 55].

Rachunek kosztów zmiennych dzieli więc koszty na te, które są bezpośrednio związane z produkcją i zależne od jej wielkości, oraz na te, które nie zależą od produkcji. Sposób ujmowania kosztów w rachunku kosztów zmiennych przedstawia rysunek 1 .

Zmienne koszty wytworzenia produktów poniesione w okresie sprawozdawczym są rozliczane na wytworzone produkty gotowe i produkty niezakoń- 


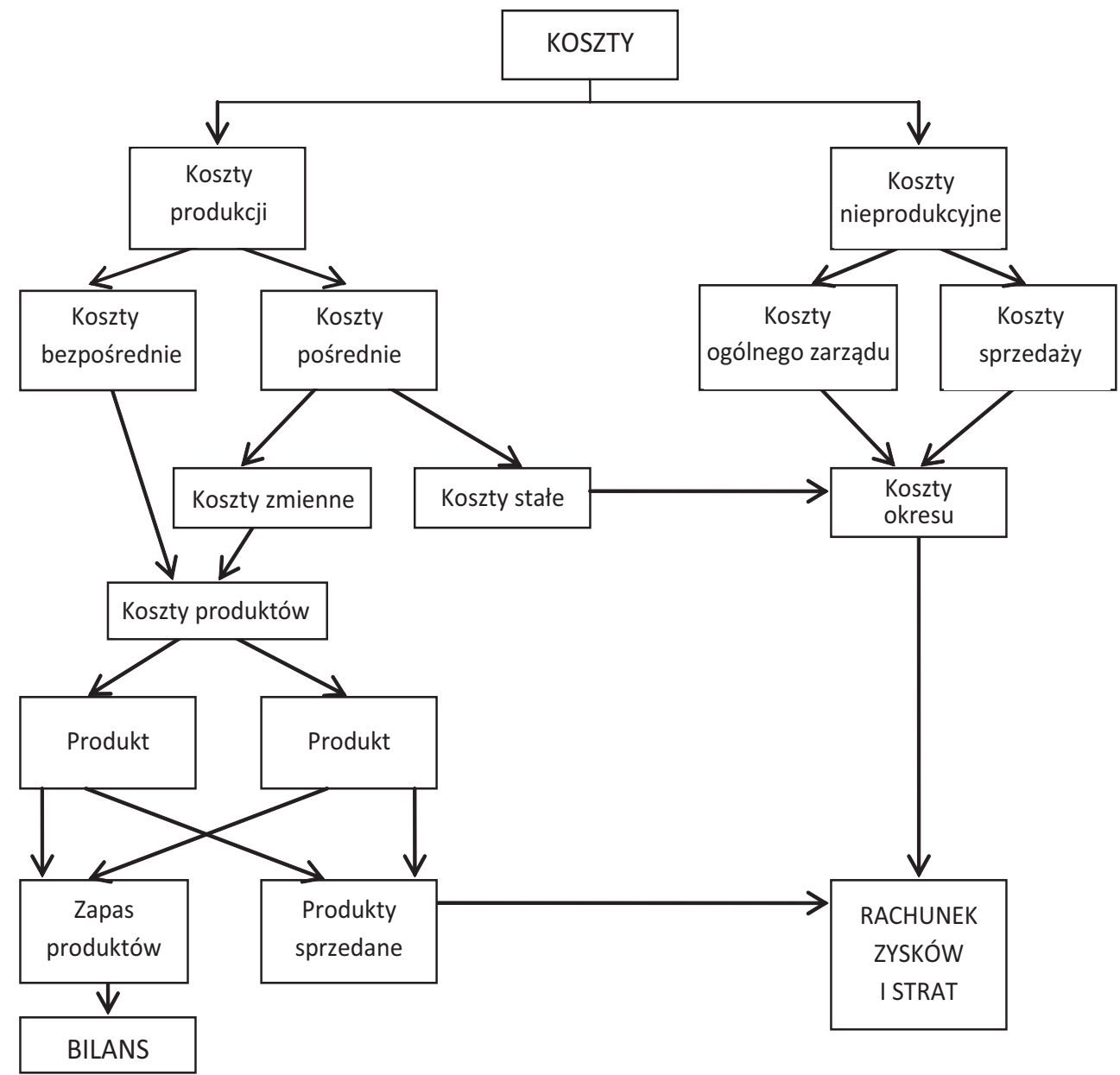

\section{Rysunek 1}

Koszty działalności przedsiębiorstwa w systemie rachunku kosztów zmiennych

Źródło: E. Nowak, R. Piechota, M. Wierzbiński, Rachunek kosztów w zarządzaniu przedsiębiorstwem, PWE, Warszawa 2004.

czone (półprodukty i produkty w toku). Zmienne koszty wytworzenia produktów (produktów gotowych i produktów niezakończonych) poniesione w okresie sa następnie rozliczane na produkty niesprzedane oraz produkty sprzedane. Koszty wytworzenia produktów niesprzedanych, które stanowią zapas, są wykazywane w bilansie. Z kolei koszty wytworzenia produktów sprzedanych są wykazywane w rachunku zysków i strat jako element kosztów własnych sprzedanych produktów [Nowak i in. 2004, s. 52]. 
Zaletą stosowania rachunku kosztów zmiennych jest generowanie realnych informacji o jednostkowym koszcie zmiennym wyrobu oraz kosztach zmiennych całego przedsiębiorstwa wynikających z zależności wielkości produkcji i wielkości zużycia czynników produkcji.

Za pomocą rachunku kosztów zmiennych można kontrolować proces powstawania kosztów w przedsiębiorstwie, a zwłaszcza wielkość i strukturę kosztów stałych, zależnych od posiadanego potencjału produkcyjnego. Rachunek kosztów zmiennych ułatwia przedsiębiorstwu podejmowanie trafnych decyzji cenowych przez określenie dolnego i górnego poziomu cen wyrobu, ustalenie opłacalności sprzedaży na określonych rynkach, a także szybsze dostosowanie się do zmian na nich zachodzących [Nowak i in. 2004, s. 50].

Słabością rachunku kosztów zmiennych jest ewentualność wystąpienia praktycznych trudności z podziałem kosztów na koszty stałe i koszty zmienne, a także ograniczone możliwości zastosowania w procesie podejmowania decyzji dhugookresowych [Gabrusewicz i in. 1998, s. 81].

Rachunek kosztów zmiennych jest tym systemem rachunku kosztów, który był do niedawna najczęściej wykorzystywany w zarządzaniu przedsiębiorstwem, przy czym rachunek kosztów zmiennych dostarcza informacji przydatnych w zarządzaniu w krótkim okresie. Ponieważ planowanie długookresowe w środowisku permanentnie zmiennym i innowacyjnym nie jest możliwe, pozostaje ciagłe zarządzanie krótkoterminowe kosztami i stąd ponowne zainteresowanie tym (z pozoru) prostym narzędziem - rachunkiem kosztów zmiennych. Chodzi tu przede wszystkim o podejmowanie decyzji: ekonomicznych, wymagających dostosowania się do zmian zachodzących na rynku oraz decyzji w warunkach niewykorzystanych zdolności produkcyjnych [Nowak i in. 2004, s. 69].

Ważnym obszarem wykorzystania informacji z rachunku kosztów zmiennych jest ustalenie wielkości produkcji zapewniającej osiagnnięcie rentowności. Temu celowi służy analiza progu rentowności, która jest metodą badania relacji między zmianami wielkości produkcji i sprzedaży a zmianami kosztów, przychodów i wyników ze sprzedaży [Nowak s. 69].

Próg rentowności stanowi narzędzie wykorzystywane do podejmowania decyzji dotyczących optymalnej ceny danego wyrobu, kosztów jakie na nie należy ponieść oraz wielkości produkcji. Krytyczną wartość stanowi punkt, po przekroczeniu którego przychody zaczynają przewyższać koszty, a decyzje stają się opłacalne. W standardowej postaci analizy progu rentowności przyjmuje się kilka założeń. Po pierwsze, wytwarzany i sprzedawany jest pojedynczy wyrób, po drugie - koszty poniesione w ciagu badanego okresu traktowane sa jako wydatek tego okresu, kolejno wielkość produkcji jest równa wielkości sprzedaży oraz koszty i przychody całkowite są liniowymi funkcjami wielkości produkcji [Nowak 1995, s. 69-70]. 
Graficzną interpretację progu rentowności przedstawiono na rysunku 2.

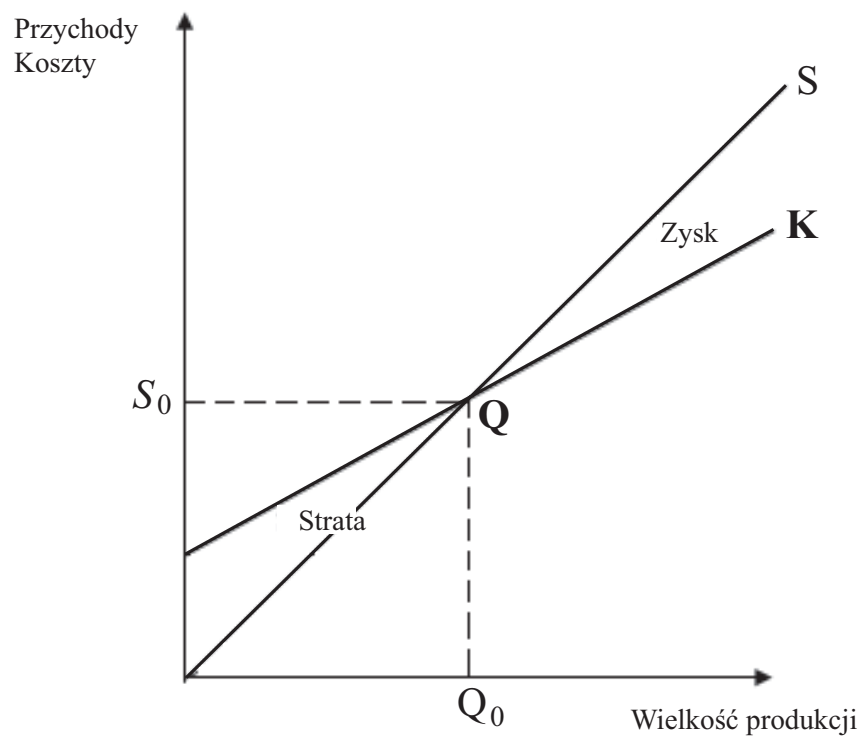

\section{Rysunek 1}

Graficzna ilustracja progu rentowności

Źródło: E. Nowak, Rachunkowość menadżerska, Wydawnictwo Akademii Ekonomicznej, Wrocław 1995, s. 72.

Na rysunku 2 dwie proste obrazują kształtowanie się kosztów całkowitych $-K$ oraz całkowitego przychodu ze sprzedaży $-S$ przy określonej wielkości produkcji $-Q$. Punkt przecięcia tych prostych stanowi próg rentowności $\left(Q_{0}\right.$ - ilościowy, $S_{0}$ - wartościowy). Obszar pomiędzy prostymi $S$ i $K$ przedstawia wynik finansowy - stratę dla produkcji mniejszej od $Q_{0}$ oraz zysk dla produkcji większej od $Q_{0}$ [Piosik 2006, s. 143].

Niestety zastosowanie powyższej zależności wprost w praktycznych warunkach nie jest możliwe, choćby z tego powodu, że koszty nie zmieniają się wprost proporcjonalnie. Praktycy modyfikują więc powyższą formułę i powyżej opisany rachunek kosztów, tworząc użyteczne rodzaje. Literatura opisuje dwie odmiany rachunku kosztów zmiennych: wielostopniowy i wieloblokowy rachunek kosztów zmiennych.

Wielostopniowy rachunek kosztów zmiennych zakłada rozpatrywanie kosztów stałych w określonych segmentach, które są przyporządkowane różnym rodzajom działalności przedsiębiorstwa. Zazwyczaj wyróżnia się następujące segmenty kosztów stałych:

- stałe koszty wydziałowe, 
- koszty sprzedaży,

- koszty ogólnego zarządu.

Rachunki wielostopniowe uwzględniają hierarchę kosztów i umożliwiają planowanie i kontrolę wyniku w warunkach bardziej złożonych. Zastosowanie rachunku wielostopniowego jest podstawą rozwoju analiz na poziomie zarządzania operacyjnego.

Drugą odmianą segmentowego rachunku kosztów zmiennych jest wielkoblokowy rachunek kosztów zmiennych, który zakłada rozpatrzenie kosztów stałych w pewnych blokach przyporządkowanych różnym zakresom podmiotowym i przedmiotowym. Ma on zastosowanie głównie w przedsiębiorstwach wielooddziałowych i przy produkcji wieloasortymentowej [Nowak i in. 2004, rozdział 3].

\section{Wycena wyrobów i wyniku finansowego w rachunku kosztów zmiennych}

Koszty zmienne w rachunku kosztów zmiennych traktowane sąjako „koszty produktów" i stosowane są do wyceny wytworzenia produktów. Wszystkie koszty stałe niezależnie od tego, jaki jest ich związek z procesem produkcji traktowane są jako koszty okresu. Koszty sprzedaży, koszty ogólnego zarządu oraz stałe koszty produkcyjne obciążają wynik w momencie ich poniesienia. Rachunek ten wykorzystywany jest w bieżącym zarządzaniu w przedsiębiorstwie.

Sposób ustalenia wyniku operacyjnego ze sprzedaży w konsekwencji rachunku kosztów zmiennych przedstawiono w tabeli 1.

Tabela 1

Rachunek zysków i strat przy zastosowaniu rachunku kosztów zmiennych

\begin{tabular}{|l|}
\hline Przychody ze sprzedaży \\
- Koszty zmienne wyrobów \\
- Koszty zmienne sprzedaży i ogólnego zarządu \\
\hline$=$ Marża na pokrycie \\
- Koszty stałe produkcyjne \\
- Koszty stałe sprzedaży i ogólnego zarządu \\
\hline = Wynik ze sprzedaży
\end{tabular}

Źródło: J. Matuszek, M. Kołosowski, Z. Krokosz-Krynke, Rachunek kosztów dla inżynierów, PWE, Warszawa 2011, s. 62.

Wielkość marży na pokrycie jest uzależniona bezpośrednio od rozmiarów sprzedaży. Ponieważ zakłada się, że koszty stałe nie zmieniają się, wysokość 
marży na pokrycie ma bezpośredni wpływ na wynik ze sprzedaży. Wynik finansowy w rachunku kosztów zmiennych jest ustalony w sposób stopniowy, najpierw ustalony jest wynik brutto I, będący różnicą między przychodami a kosztami zamiennymi wytworzenia produktów. Następnie jest ustalony wynik brutto II, tzw. marża pokrycia kosztów stałych oraz zysku. W przypadku, gdy marża na pokrycie wystarcza jedynie na pokrycie kosztów stałych, wynik ze sprzedaży wyniesie zero. Jeśli natomiast marża na pokrycie nie pokrywa kosztów stałych, pojawia się strata na sprzedaży, jeśli zaś jest wyższa niż koszty stałe, przedsiębiorstwo wypracowuje zysk ze sprzedaży.

W ramach kosztów zmiennych cechą charakterystyczną jest dzielenie technicznych kosztów wytwarzania na zmienną i stałą część. Wyroby gotowe i produkcję niezakończoną wycenia się wyłącznie na podstawie kosztów zmiennych (koszty bezpośrednie oraz część kosztów wydziałowych zmiennych). Stałe koszty wydziałowe w rachunku kosztów zmiennych są odnoszone wprost do wyniku finansowego danego okresu. Inne jest tu podejście niż w rachunku kosztów pełnych, koszty zarządu i sprzedaży obciążają bezpośrednio rachunek wyników danego okresu sprawozdawczego, a technicznymi kosztami są obciążone wyroby gotowe i produkcja niezakończona. Różnica między dwoma rachunkami kosztów polega na innym podejściu do kosztów produkcyjnych. W rachunku kosztów pełnych są one aktywowane jako wartość zapasów, a w rachunku kosztów zmiennych obciążają wynik okresu. Obydwie koncepcje w inny sposób podchodzą do wyceny zapasów. W przypadku, kiedy produkcja nie jest równa sprzedaży, pojawiają się różnice w wysokości wyniku ze sprzedaży.

\section{Rachunek kosztów zmiennych w przedsiębiorstwie X}

W badanym przedsiębiorstwie ma zastosowanie rachunek kosztów pełnych. W związku z przejściowymi trudnościami w sprzedaży wyrobów, po dotychczasowych cenach kalkulowanych na poziomie kosztów całkowitych, podjęto próbę ustalenia ceny na poziomie kosztów zmiennych. Wybrano ten rachunek w związku z zaletami tego narzędzia: ułatwienie podejmowania trafnych decyzji cenowych przez określenie dolnej i górnej ceny oraz opłacalności produkcji i sprzedaży wyrobów.

Przedsiębiorstwo dzieli się na 12 działów, każdy zajmujący się czymś odrębnym i mającym wyspecjalizowanych pracowników. Takimi działami są: zarząd, przygotowanie produkcji, formowanie, ustawka, sortownia, ogólny dział produkcji, działy badawczo-rozwojowy, kontroli jakości, serwisu, inwestycji i rozwoju, handlowy oraz logistyki. Konsekwencją takiego podziału organizacyjnego jest struktura kosztów w rachunku kosztów. 
W przedsiębiorstwie wyodrębniono następujące kategorie kosztów operacyjnych:

- 501. Koszty przygotowania produkcji,

- 502. Koszty produkcji (koszty bezpośrednie formowania, ustawiania, sortowania, ogólne produkcji),

- 526. Koszty wydziałowe,

- 527. Koszty sprzedaży,

- $\quad$ 531. Koszty pomocnicze - obsługi technicznej (serwis techniczny),

- 532. Koszty pomocnicze - kontrola jakości,

- 550. Koszty zarządu,

- 550-09. Koszty magazynowania.

Koszty te stanowią podstawę wyceny wyrobów gotowych dla celów sprawozdawczych i podatkowych. Kosztami okresu są koszty zarządu i koszty sprzedaży.

Punktem wyjścia do analizy kosztów zmiennych było ustalenie rodzaju i wielkości kosztów ponoszonych $\mathrm{w}$ przedsiębiorstwie. Wykorzystano dane zgromadzone na kontach księgowych zespołu 5 zakładowego planu kont. Wartość kosztów ponoszonych w badanym okresie przedstawia tabela 2 .

Koszty przygotowania produkcji to materiały składające się na wyrób oraz praca ludzi niezbędna do przygotowania odpowiedniego składu materiałów. Koszty produkcji to zasadniczo wynagrodzenia, amortyzacja maszyn produkcyjnych oraz gaz wykorzystywany do wypału produktów. Pozostałe koszty wymienione w tabeli zawierają standardowe pozycje kosztów prostych. Rozmiar produkcji w kilogramach i metrach kwadratowych w poszczególnych miesiącach został przedstawiony w tabeli 3 .

Rozmiar produkcji w tych dwóch jednostkach ewidencjonowany jest $\mathrm{w}$ dziale rozliczeń produkcji. Odpowiada on ilości przyjętych na magazyn w danym miesiącu wyrobów gotowych i ich wadze wyrażonej w kilogramach oraz powierzchni ułożenia wyrażonej $\mathrm{w}$ metrach kwadratowych (standardową wagę i powierzchnię ustalono w normach produkcji i podlegają one weryfikacji przez dział kontroli jakości). Jedynie koszty pomocnicze - obsługi technicznej, kontroli jakości i inwestycji i rozwoju - pozostają w kolejnych okresach podobne. Miesięczne koszty własne wynoszą ponad $2 \mathrm{mln}$ zł i mieszczą się w przedziale miedzy 2,07 a 2,38 mln zł. Pozostałe koszty zmieniają się znacząco w kolejnych okresach ale bez związku ze zmianami w rozmiarze produkcji. Ustalono więc dynamikę zmiany tych kosztów w stosunku do pierwszego okresu sprawozdawczego - stycznia 2014 roku, co przedstawia tabela 4.

Największą zmienność w stosunku do stycznia przedstawiają koszty przygotowania produkcji, koszty produkcji oraz sprzedaży i zarządu. Oczywiście te ostatnie koszty nie mają nic wspólnego z rozmiarem produkcji. Koszty przy- 

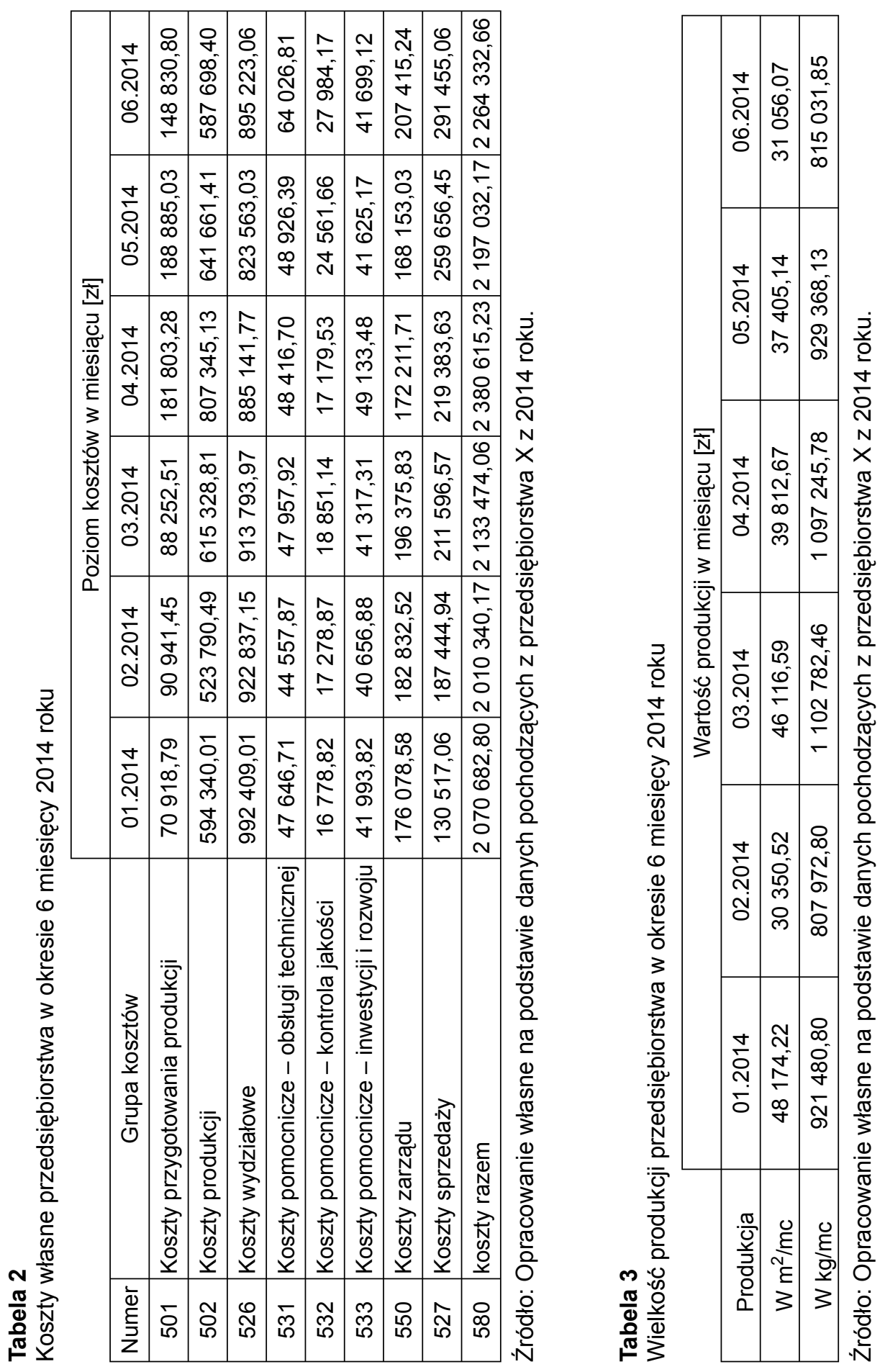


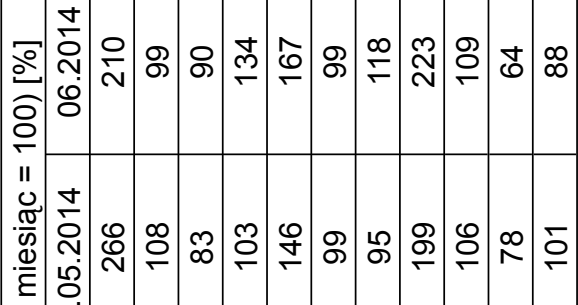

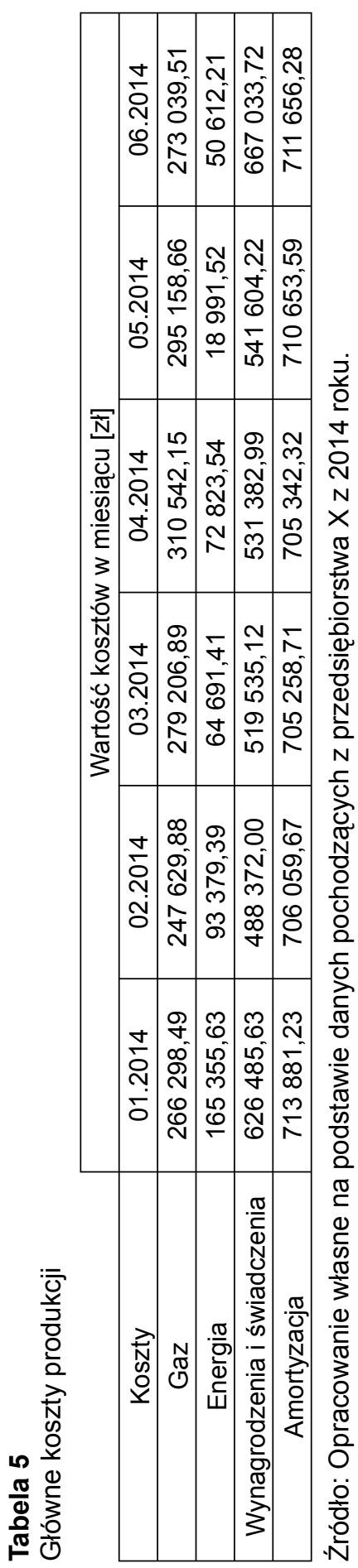


gotowania i produkcji wzrastają w kolejnych miesiącach w stosunku do stycznia. Jednak podobnej zmiany nie obserwujemy w rozmiarze produkcji, zarówno w kilogramach, jak i w metrach. Wręcz przeciwnie, w przypadku produkcji wyrażonej $\mathrm{w}$ metrach rejestrujemy spadek $\mathrm{w}$ stosunku do danych ze stycznia 2014 roku. Wynika z powyższego, iż koszty w teorii uznawane za zmienne, w przypadku badanego przedsiębiorstwa nie są związane z rozmiarem produkcji. Ostrożniej wnioskując można stwierdzić, iż zarejestrowany przyrost kosztów $\mathrm{w}$ większym stopniu jest spowodowany czynnikami innymi niż rozmiar produkcji. W związku z powyższym konieczna jest weryfikacja zmienności kosztów prostych składających się na poszczególne, wymienione w tabelach, kategorie kosztów złożonych.

Z analizy zapisów szczegółowych na kontach kosztów ustalono, iż zmiennymi i największymi kategoriami kosztów produkcji w przedsiębiorstwie są pozycje zaprezentowane $\mathrm{w}$ tabeli 5 .

Jak wynika z tabeli 5 , to koszty energii, gazu technologicznego i wynagrodzeń stanowią największe pozycje składające się na koszty produkcji. Koszty te zmieniały się w stosunku do stycznia 2014 roku w sposób zaprezentowany w tabeli 6 .

Odnosząc powyższe zmiany do zmian w rozmiarze produkcji, można stwierdzić, że jedynie gaz jest kosztem zmieniającym się w tej samej tendencji. Pozostałe koszty zmieniają się bez wyraźnego związku z rozmiarem produkcji. Wnioskowanie o zmienności kosztów ma więc charakter intuicyjny, a dane ewidencyjne mogą utrudnić prawidłową ich identyfikację.

Ponieważ przedsiębiorstwo produkuje dwa asortymenty, korzystając z tych samych materiałów (surowców), które są obrabiane na dwóch niezależnych liniach technologicznych, i zespołów pracowników bezpośrednio produkcyjnych dla celów zarządczych, wydzielono ich koszty bezpośrednie, a koszty pośrednie rozliczono w relacji do wielkości produkcji wyrażonej w kilogramach.

\section{Tabela 6}

Główne koszty produkcji

\begin{tabular}{|l|c|c|c|c|c|c|}
\cline { 2 - 7 } \multicolumn{1}{c|}{} & \multicolumn{6}{c|}{ Dynamika zmian poziomu kosztów [\%] } \\
\hline Koszty & 01.2014 & 02.2014 & 03.2014 & 04.2014 & 05.2014 & 06.2014 \\
\hline Gaz & 100 & 93 & 105 & 117 & 111 & 103 \\
\hline Energia & 100 & 56 & 39 & 44 & 11 & 31 \\
\hline Wynagrodzenia i świadczenia & 100 & 78 & 83 & 85 & 86 & 106 \\
\hline Amortyzacja & 100 & 99 & 99 & 99 & 100 & 100 \\
\hline Produkcja w m²/mc & 100 & 63 & 96 & 83 & 78 & 64 \\
\hline Produkcja w kg/mc & 100 & 88 & 120 & 119 & 101 & 88 \\
\hline
\end{tabular}

Źródło: Opracowanie własne na podstawie danych pochodzących z przedsiębiorstwa $X$ z 2014 roku. 


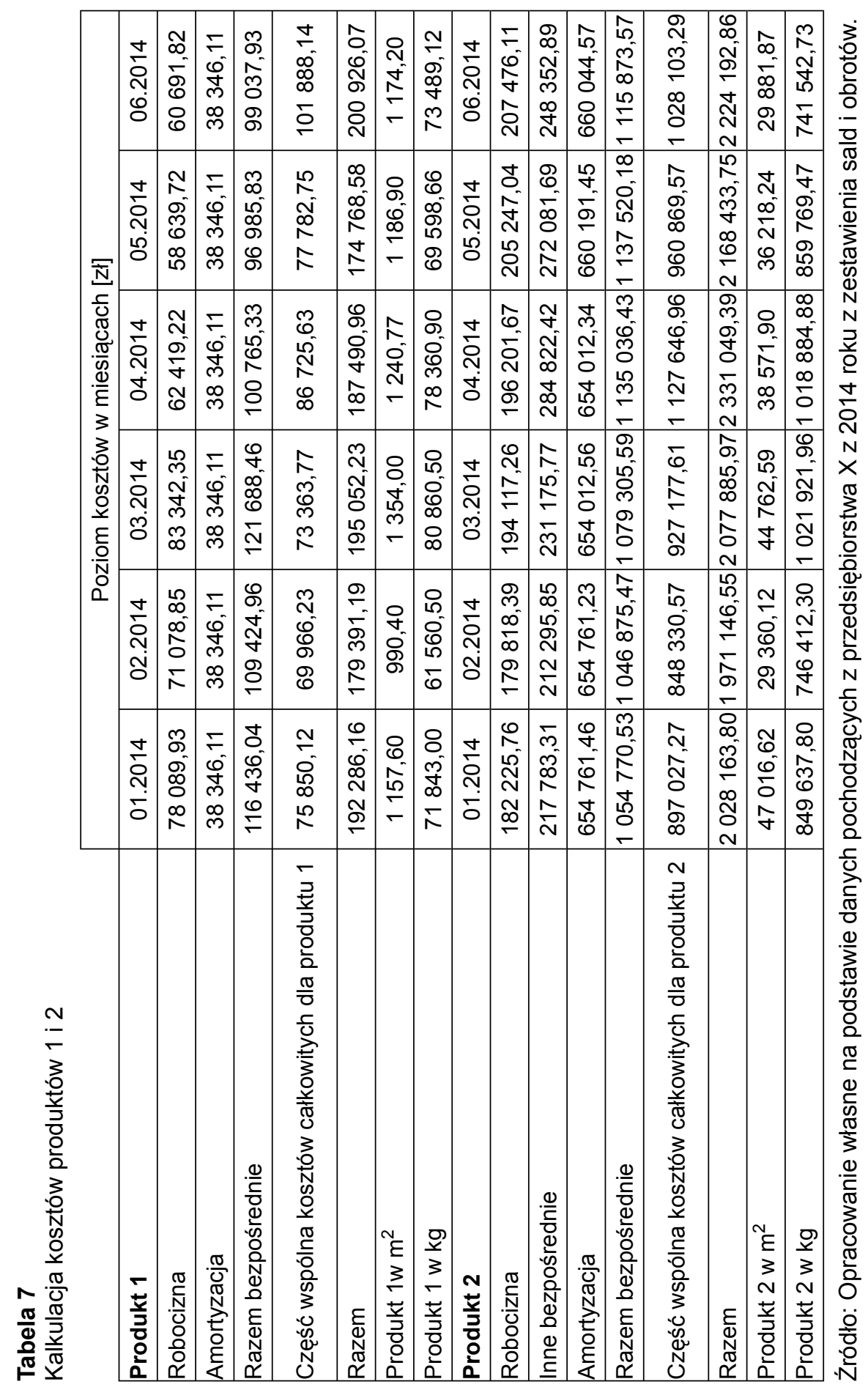


Ponieważ każdy z produktów powstaje przy użyciu innych maszyn produkcyjnych, amortyzację uznano za koszty bezpośrednie i wyłączono z kosztów wspólnych. Koszty inne niż robocizna, amortyzacja i materiały bezpośrednie uznano za koszty wspólne i rozdzielono je w relacji do wagi wytworzonych wyrobów. Zasadniczo przedsiębiorstwo produkuje wyrób 2, który stanowi 95\% produkcji przedsiębiorstwa.

$\mathrm{Z}$ zestawienia stosowanego przez przedsiębiorstwo dla celów zarządczych wynika, iż koszty robocizny materiałów, czyli zmienne koszty produkcji, wartościowo są niewielkie i nie mają większego znaczenia w kształtowaniu ceny wyrobów.

Ponieważ zastosowanie zmiennego rachunku kosztów wymaga dodatkowych działań: wydzielenie segmentów kosztów, zbadanie zmienności poszczególnych kosztów na poziomie analitycznym oraz ustalenie jednostek kalkulacyjnych, zarząd przedsiębiorstwa doszedł do wniosku, iż zadania takie są czasochłonne i w związku z nieznaczną wartością kosztów zmiennych dalsze działania kalkulacyjne przy zastosowaniu tej metody nie będą prowadzone.

\section{Wnioski}

Zastosowanie nawet prostego rachunku kosztów zmiennych nastręcza problemów i rodzi konieczność poniesienia znacznego nakładu pracy i pieniędzy. Zasadniczą kwestią utrudniającą wprowadzenie rachunku kosztów zmiennych, a jednocześnie dyskwalifikującą go $\mathrm{w}$ wybranym przedsiębiorstwie jest fakt, iż główna część kosztów związanych z procesem produkcji ma charakter kosztów pośrednich/stałych, niewrażliwych na zmiany poziomu produkcji.

Menedżerowie w średnich i małych przedsiębiorstwach nie są skłonni korzystać z takich narzędzi optymalizacji i analizy kosztów, wolą czas swój i zespołu, energię i pieniądze przeznaczyć na maksymalizowanie przychodów - działania marketingowe, sprzedażowe.

$\mathrm{Z}$ doświadczeń praktyki i badań wynika, że wiele opisywanych w teorii narzędzi nie znajduje zastosowania, choć niewątpliwie systematyzuje wiedzę i w sposób selektywny może być użyteczne w praktyce.

\section{Literatura}

GABRUSEWICZ W., KAMELA-SOWIŃSKA A., POETSCHKE H., 1998: Rachunkowość zarzqdcza, PWE, Warszawa.

JARUGOWA A., SOBAŃSKA I., SOCHACKA R., 1994: Metody kalkulacji. Koszty, ceny, decyzje, PWE, Warszawa. 
MATUSZEK J., KOŁOSOWSKI M., KROKOSZ-KRYNKE Z., 2011: Rachunek kosztów dla inżynierów, PWE, Warszawa.

MATUSZEWICZ J., MATUSZEWICZ P., 1999: Rachunkowość od podstaw, FINANS-SERWIS Zespół Doradców Finansowo-Księgowych, Warszawa.

NOWAK E., 1995: Rachunkowość menadżerska, Wydawnictwo Akademii Ekonomicznej, Wrocław.

NOWAK E., 2002: Rachunkowość. Kurs podstawowy, PWE, wyd. II, Warszawa.

NOWAK E., PIECHOTA R., WIERZBIŃSKI M., 2004: Rachunek kosztów w zarzadzaniu przedsiębiorstwem, PWE, Warszawa,

PIOSIK A., 2006: Zasady rachunkowości zarzadczej, Wydawnictwo Naukowe PWN, Warszawa.

SOBAŃSKA I., 2003: Rachunek kosztów i rachunkowość zarzadcza, Wydawnictwo C.H. BECK, Warszawa.

ŚWIDERSKA G.K. (red.), 2003: Rachunkowość zarzqdcza i rachunek kosztów, tom 1, Difin, Warszawa.

\section{Multi-stage direct costing in a selected enterprise}

\section{Abstract}

This article presents the assumptions of direct costing and its importance in shaping the prices of manufactured products. The article discusses the results of the costs analysis and attempts to implement direct costing in a selected company. Research has proven that this method should not be applied to all enterprises. The main issue hindering the implementation of direct costing, and at the same time disqualifying it in the selected enterprise is the fact that a substantial portion of the costs associated with the production process are either indirect or fixed costs, thus being not sensitive to changes in production level. 